Brazilian Journal

of Chemical

\title{
CHARACTERIZATION AND BEHAVIOUR OF PT CATALYSTS SUPPORTED ON BASIC MATERIALS IN DRY REFORMING OF METHANE
}

\author{
Adriana D. Ballarini ${ }^{1}$, Cesário F. Virgens ${ }^{2}$, Maria C. Rangel ${ }^{3}$, \\ Sergio R. de Miguel ${ }^{1}$ and Javier M. Grau ${ }^{1 *}$ \\ ${ }^{1}$ Instituto de Investigaciones en Catálisis y Petroquímica "Ing. José Miguel Parera", Santa Fe, Argentina. \\ E-mail: aballa@fiq.unl.edu.ar; sdmiguel@fiq.unl.edu.ar; jgrau@fiq.unl.edu.ar, ORCID: 0000-0001-6209-8785 \\ ${ }^{2}$ Universidade do Estado da Bahia, Departamento de Ciências Exatas e da Terra, Colegiado do Programa de Pós-Graduação \\ em Química Aplicada, Salvador, BA, Brasil. E-mail: cvirgens@uneb.br \\ ${ }^{3}$ Universidade Federal da Bahia, Grupo de Estudos em Cinética e Catalise, Salvador, BA, Brasil. E-mail: mcarmov@ufba.br
}

(Submitted: March 21, 2017 ; Revised: April 9, 2018 ; Accepted: May 12, 2018)

\begin{abstract}
Different basic materials, such as $\mathrm{K}-\mathrm{L}$ zeolite, $\mathrm{K}-\mathrm{Al}_{2} \mathrm{O}_{3}, \mathrm{~K}-\mathrm{Mg} / \mathrm{Al}$ mixed oxide and $\mathrm{MgO}$, were used as supports of Pt-catalysts for the dry reforming of methane (DR) reaction. The effects of the distribution of basic strength in the support on the metal-support properties and catalyst performance were evaluated. The density of strong and the total basic sites decreased as follows: $\mathrm{MgO}>\mathrm{K}(\mathrm{Mg}-\mathrm{Al})>\mathrm{K}-\mathrm{Al}_{2} \mathrm{O}_{3}>\mathrm{K}-\mathrm{L}$. The total basic sites decrease from 214 to $23 \mu \mathrm{mol} \mathrm{CO}$. $\mathrm{g}^{-1}$, for $\mathrm{MgO}$ and $\mathrm{KL}$, respectively. Pt catalysts supported on materials with high density of strong basic sites such as $\mathrm{MgO}$ were the most adequate for the DR reaction. An increase in the dehydrogenation velocity of 12.1 to $25.2 \mathrm{~mol} \mathrm{~h}^{-1} \mathrm{~g}^{-1}$ was observed between $\mathrm{Pt} / \mathrm{KL}$ and Pt/MgO, which indicates a higher metallic dispersion of the latter catalyst. With respect to the DR reaction, both catalysts have a similar $\mathrm{CO}_{2}$ conversion, but the $\mathrm{CH}_{4}$ conversion and the $\mathrm{H}_{2} / \mathrm{CO}$ ratio increase from 71.1 to $83.0 \%$ and 0.5 to 0.73 , respectively. The best catalytic behaviour of $\mathrm{Pt} / \mathrm{MgO}$ would be related with the good interaction between the metal and the basic support. The methane conversion and the $\mathrm{H}_{2} / \mathrm{CO}$ ratios obtained by DR reaction correlate quite well with the basicity of the different catalysts.

Keywords: Dry reforming of $\mathrm{CH}_{4} ; \mathrm{H}_{2}$ production; Syngas; Platinum acetylacetonate (II); $\mathrm{Mg} / \mathrm{Al}$ mixed oxide; Alkaline metal-doped materials.
\end{abstract}

\section{INTRODUCTION}

The transformation of methane into syngas, a more valuable product, has attracted noticeable interest since high conversions and selectivities can be obtained. Steam reforming (SR) is the most common process that has been used for years on an industrial scale. However, this is an endothermic process with a very important energy requirement. An alternative is the methane reforming with $\mathrm{CO}_{2}$ or dry reforming (DR) that has aroused a lot of interest due to its green nature (Hileman, 1998). The operating cost analysis of this process compared to others has shown its usefulness
(Stagg and Romeo, 1998; Ballarini and de Miguel, 2005). The syngas produced by this reforming reaction is used as feedstock for various chemical processes, such as fuel cells fed with $\mathrm{H}_{2}$, methanol synthesis and Fischer-Tropsch synthesis (Seo and Young, 2009; de Miguel and Vilella 2012). Besides, the DR of methane not only has the advantage of providing a $\mathrm{H}_{2} / \mathrm{CO}$ ratio equal to 1 , more appropriate for carbonylation and hydroformylation reactions, and lower operating costs compared to the processes of SR and oxidative reforming (OR), but also brings a contribution to environmental preservation, because it consumes carbon dioxide, which is one of the greenhouse gases

\footnotetext{
*Corresponding authors: Javier M. Grau - E-mail: jgrau@fiq.unl.edu.ar
} 
(van Keulen and Hegarty, 1997; de Miguel and Vilella, 2012). Thus, this process is presented as a promising alternative to obtain both synthesis gas as well as hydrogen. The main reactions in the DR process are:

$$
\begin{aligned}
& \mathrm{CH}_{4}+\mathrm{CO}_{2} \rightleftarrows 2 \mathrm{CO}+2 \mathrm{H}_{2} \quad\left(\Delta \mathrm{H}_{298 \mathrm{~K}}^{0}=+247 \mathrm{~kJ} \mathrm{~mol}^{-1}\right) \\
& \mathrm{CO}_{2}+\mathrm{H}_{2} \rightleftarrows \mathrm{CO}+\mathrm{H}_{2} \mathrm{O} \quad\left(\Delta \mathrm{H}_{298 \mathrm{~K}}^{0}=+41 \mathrm{~kJ} \mathrm{~mol}^{-1}\right)
\end{aligned}
$$

The second reaction is always present at high temperatures and it is called the reverse water gas shift reaction (RWGS).

Great research efforts are being done in order to develop catalysts with good activity, selectivity and stability for the DR reaction. The major drawbacks and limitations of this process are the serious catalyst deactivation due to coke formation and the operation temperature, that presents an important requirement of energy due to the highly endothermic reaction (Arandiyan and Parvari, 2008; Khalesi and Arandiyan 2008). The main cause of coke formation in DR is due to the fall off of the hydrogenating activity of carbon precursors caused by metallic sintering. This is accentuated by the high operating temperature required by thermodynamics. As it is not possible to change the thermodynamics of the reactions, we must find a more stable metallic catalyst which promotes hydrogenating activity. The challenge is based on finding active catalysts with low coke formation.

Two ways are possible to decrease the rate of coke formation: i) use noble metals of greater hydrogenating capacity and greater metal-support interaction to maintain a high dispersion or ii) use basic supports. The deactivation reaction could be controlled with basic supports that would favour the dissociation of $\mathrm{CO}_{2}$ into $\mathrm{CO}$ and $\mathrm{O}$, this last specie being responsible for the metallic surface cleaning (Stagg et al, 1998). In this work we have tried both ways to improve the catalytic stability.

Noble metals ( $\mathrm{Rh}, \mathrm{Ru}, \mathrm{Pt}$ and Ir) have shown improved activity since they are more active and less sensitive to the deactivation by carbon deposition than $\mathrm{Ni}$ (Rostrup-Nielsen and Hansen, 1993). Besides, the use of metallic catalysts based on noble metals, although it is more expensive than the utilization of non-noble metals such as $\mathrm{Ni}$, presents advantages with respect to the activity and stability of the metallic phase for reactions with $\mathrm{CO}_{2}$, as in the case of dry reforming of methane. Moreover, noble metals can also be used for this reaction to promote the $\mathrm{Ni}$ catalysts in order to increase the resistance to deactivation (Pakhare and Spivey, 2014; de Miguel et al., 2012).

Some researchers have greatly enhanced the catalytic activity and stability of catalysts by adding some components to the alumina support to inhibit sintering and phase transformation. To overcome these drawbacks, recently we reported the addition of alkaline $(\mathrm{Na}, \mathrm{K})$ and alkaline earth $(\mathrm{Mg})$ metals to $\gamma-\mathrm{Al}_{2} \mathrm{O}_{3}$ (Ballarini and Basile 2012). In the literature, numerous metallic oxides such as $\mathrm{Al}_{2} \mathrm{O}_{3}, \mathrm{SiO}_{2}, \mathrm{MgO}, \mathrm{BaO}, \mathrm{CaO}$, $\mathrm{TiO}_{2}, \mathrm{ZrO}_{2}$ and $\mathrm{CeO}_{2}$ have been investigated as supports for dry reforming of methane (Fan and Abdullah 2009; Mehran Rezaeia and Meshkania 2014; Ballarini et al., 2005; Nagaoka et al., 2004; Ozkara-Aydinoglu et al., 2009; Sadykov at al., 2011; Garcia-Dieguez et al., 2010; Ozkara-Aydinoglu and Aksoylu, 2011; OzkaraAydinoglu and Aksoylu, 2013; Adans et al., 2017).

It is well known that the introduction of $\mathrm{Pt}$ into porous alumina is carried out by impregnation with an aqueous solution of $\mathrm{H}_{2} \mathrm{PtCl}_{6}$ precursor. Previous works on $\mathrm{H}_{2} \mathrm{PtCl}_{6}$ (Berdala and Freund, 1986; Shelimov and Lambert 1999; Womes and Cholley, 2005) have shown that the interaction between the metallic precursor and the surface depends critically on the nature of the surface sites. For the impregnation of Pt on a basic support, $\mathrm{Pt}\left(\mathrm{NH}_{3}\right)_{4}\left(\mathrm{NO}_{3}\right)_{2}$ or platinum acetylacetonate $\left[\mathrm{Pt}(\mathrm{acac})_{2}\right]$ can be used as a precursor. In contrast to $\mathrm{Pt}\left(\mathrm{NH}_{3}\right)_{4}\left(\mathrm{NO}_{3}\right)_{2}$, there is little information about the interaction between $\mathrm{Pt}(\mathrm{acac})$, and alumina. Womes et al. (2003) showed that the interaction between $\mathrm{Pt}(\mathrm{acac})_{2}$ and alumina surfaces is weak but, after calcination at $623 \mathrm{~K}$, there is a complete decomposition of the complexes and an oxidation of all platinum to $\mathrm{Pt}^{4+}$, thus leading to a dispersed state. An alternative route to obtain well-dispersed $\mathrm{Pt}$ on the alumina is by impregnating the alumina with a solution of $\mathrm{Pt}(\mathrm{acac})_{2}$ in organic solvents such as toluene, benzene or dichloromethane (Coq and Crabb 1994; Walter and Coq 1995; de Menorval and Chaqroune 1997; Gandao and Coq 1996; Reyes and Pecchi 1997, Al-Doghachi et al., 2015).

This work studies the influence of the use of different basic supports on the catalytic performance in dry reforming of methane of Pt-catalysts prepared by the impregnation with an organometallic precursor (platinum acetylacetonate (II) solution in toluene:acetone (1:1)). The acidity-basicity of the supports was studied by temperature-programmed desorption of $\mathrm{NH}_{3}$ or $\mathrm{CO}_{2}$, and 2-propanol decomposition. Catalysts were characterized by test reactions of the metallic phase (cyclohexane dehydrogenation), temperature-programmed reduction and FTIR spectroscopy of the adsorbed CO in order to find a relationship between the catalyst metallic structure and the catalytic performance (activity, selectivity and stability) in the Dry Reforming reaction.

\section{MATERIALS AND METHODS}

\section{Catalysts preparation}

Several supports were used, viz:

i) Commercial $\gamma-\mathrm{Al}_{2} \mathrm{O}_{3}$ (Cyanamid Ketjen, CK-300; $\mathrm{S}_{\mathrm{BET}}$ : $190 \mathrm{~m}^{2} \mathrm{~g}^{-1}$ ) was added as a reference. 
$\mathrm{K}$ doped $\gamma-\mathrm{Al}_{2} \mathrm{O}_{3}\left(\mathrm{~S}_{\mathrm{BET}}: 176 \mathrm{~m}^{2} \mathrm{~g}^{-1}\right)$ was prepared by impregnation of CK-300 with $1 \mathrm{wt} \% \mathrm{KOH}$ (Merck, p.a.) aqueous solution using an impregnating volume relative to the weight of alumina of $1.4 \mathrm{~cm}^{3} \mathrm{~g}^{-1}$. Before the doping, the support was calcined for $3 \mathrm{~h}$ at $773 \mathrm{~K}$. The support was named K-A.

ii) Commercial KL zeolite (Union Carbide, SK45; $\mathrm{S}_{\mathrm{BET}}: 245 \mathrm{~m}^{2} \mathrm{~g}^{-1}$ ) was calcined in air at $873 \mathrm{~K}$ for $3 \mathrm{~h}$.

iii) Commercial $\mathrm{MgO}$ (Alfa Aesar 99.95\%) was hydrated with water and the resulting $\mathrm{Mg}(\mathrm{OH})_{2}$ was calcined in $\mathrm{N}_{2}$ for $18 \mathrm{~h}$ at $773 \mathrm{~K}$, the resulting support having $\mathrm{S}_{\mathrm{BET}}: 160 \mathrm{~m}^{2} \mathrm{~g}^{-1}$.

iv) Synthesized mixed oxide $\mathrm{K}(\mathrm{Mg}-\mathrm{Al})\left(\mathrm{S}_{\mathrm{BET}}\right.$ : $\left.160 \mathrm{~m}^{2} \mathrm{~g}^{-1}\right)$ prepared by co-precipitation of magnesium and aluminium nitrates at $333 \mathrm{~K}$. The $\mathrm{pH}$ was adjusted to 10 with aqueous solution of $\mathrm{K}_{2} \mathrm{CO}_{3}+$ $\mathrm{KOH}$. The precipitate was repeatedly washed with hot demineralized water and dried at $353 \mathrm{~K}$. Then it was impregnated with a solution of $\mathrm{KOH}$ and calcined in air at $773 \mathrm{~K}$. The mixed oxide had a molar $\mathrm{Mg} / \mathrm{Al}$ ratio $=1.3$ with $1 \mathrm{wt} \% \mathrm{~K}$. This support was named as $\mathrm{K}(\mathrm{Mg}-\mathrm{A})$.

The supports were homogenized, pelletized and crushed to 35 and 80 mesh particle size. All solids were heated at a rate of $3 \mathrm{~K}$. $\mathrm{min}^{-1}$ under air flow to $573 \mathrm{~K}$ and held at this temperature for $1 \mathrm{~h}$. Then, they were heated at a rate of $7 \mathrm{~K}$. $\mathrm{min}^{-1}$ to $773 \mathrm{~K}$ and kept at this temperature for $2 \mathrm{~h}$.

The catalysts were prepared by impregnation of the supports with a solution of platinum acetylacetonate (II) $97 \%$ dissolved in a solution of toluene and acetone (1:1) to obtain Pt loading of $1 \mathrm{wt} . \%$. Then they were stabilized for $12 \mathrm{~h}$ at room temperature and then heated from $303 \mathrm{~K}$ (at $3 \mathrm{~K} \cdot \mathrm{min}^{-1}$ ) to $393 \mathrm{~K}$ and maintained at this temperature for $12 \mathrm{~h}$. Calcinations of the materials were carried out under a flow of air with a heating rate of $3 \mathrm{~K} \mathrm{~min}^{-1}$ until $623 \mathrm{~K}$ and held at this temperature for $3 \mathrm{~h}$. The catalysts obtained were labelled as: $\mathrm{Pt} / \mathrm{KA}$, $\mathrm{Pt} / \mathrm{KL}, \mathrm{Pt} / \mathrm{MgO}$ and $\mathrm{Pt} / \mathrm{K}(\mathrm{Mg}-\mathrm{A})$.

\section{Characterization of the samples}

The supports were characterized by determination of specific surface area and pore volume, $\mathrm{NH}_{3}$ and $\mathrm{CO}_{2}$ adsorption and desorption experiments and 2-propanol (IPA) dehydrogenation reaction.

The specific surface was measured in a volumetric system from $\mathrm{N}_{2}$ adsorption isotherms obtained at $77 \mathrm{~K}$. The specific surface area (BET method) and porosity measurements were performed in a model ASAP 2020 Micromeritics apparatus on $0.3 \mathrm{~g}$ of samples, which were outgassed by heat under vacuum $\left(10^{-6}\right.$ Torr $)$ at $523 \mathrm{~K}$ for $30 \mathrm{~h}$ before the nitrogen adsorption.

The basic character and total basic site densities $(\mathrm{nb})$ of the supports $(0.3 \mathrm{~g})$ were determined by $\mathrm{CO}_{2}$ adsorption and desorption experiments. The $\mathrm{CO}_{2}$ adsorption was carried out at room temperature using a flow of $\mathrm{CO}_{2}(5 \%) / \mathrm{N}_{2}\left(50 \mathrm{~cm}^{3} \mathrm{~min}^{-1}\right)$, and the desorption was studied by Temperature Programmed Desorption (TPD) from $298 \mathrm{~K}$ up to $1023 \mathrm{~K}$ at $5 \mathrm{~K} \mathrm{~min}^{-1}$ using a thermal conductivity detector to measure the response.

The measurements of the density of acid sites for the different supports were also determined by using TPD of $\mathrm{NH}_{3}$. The samples were first treated with helium $(\sim 100$ $\left.\mathrm{cm}^{3} \mathrm{~min}^{-1}\right)$ at $673 \mathrm{~K}$ for $0.5 \mathrm{~h}$ and exposed to a gas stream of $1.1 \% \mathrm{NH}_{3} / \mathrm{He}$ at room temperature until all $\mathrm{NH}_{3}$ was adsorbed. Then the temperature was raised to $673 \mathrm{~K}$ at a rate of $10 \mathrm{~K} \mathrm{~min}^{-1}$ and the $\mathrm{NH}_{3}$ concentration in the effluent was measured in the mass spectrometer (MS).

The basic properties of the supports were also determined by the isopropanol (IPA) dehydrogenation reaction to acetone at $523 \mathrm{~K}$ and atmospheric pressure in a flow reactor, using a $\mathrm{N}_{2} /$ IPA molar ratio equal to 12 and a WHSV of $32 \mathrm{~h}^{-1}$. The conversion was kept at similar conversions level (10-15\%).

Platinum catalysts were characterized by temperature programmed reduction (TPR), cyclohexane dehydrogenation test reaction (DCH) and FTIR spectroscopy to study the characteristics of metallic particles.

Temperature programmed reduction analysis were done in a Micromeritics TPD/TPR 2900 device. Previously catalysts were calcined at $623 \mathrm{~K}$ in air flow with $(160 \mathrm{ml} \mathrm{min}-1)$ for $3 \mathrm{~h}$. Before the tests, $\mathrm{N}_{2}$ flow was passed. $0.5 \mathrm{~g}$ of catalyst were heated at $6 \mathrm{~K} \mathrm{~min}^{-1}$ from room temperature up to $1173 \mathrm{~K}$ under a reductive mixture of $\mathrm{H}_{2}(5 \mathrm{v} / \mathrm{v} \%) / \mathrm{N}_{2}\left(10 \mathrm{~cm}^{3} \mathrm{~min}^{-1}\right)$.

The test reaction of the metallic phase $(\mathrm{DCH})$ was carried out in a differential flow reactor at 1 bar with a $\mathrm{H}_{2} / \mathrm{CH}$ molar ratio of 16 and $\mathrm{WHSV}=12.6$ $\mathrm{h}^{-1}$. The reaction temperature was $573 \mathrm{~K}$ for the reaction. The reaction products were analysed by gas chromatography with a Chromosorb column and a FID detector. The catalysts $(0.1 \mathrm{~g})$ were previously reduced at $823 \mathrm{~K}$ under flowing $\mathrm{H}_{2}\left(60 \mathrm{~cm}^{3} \mathrm{~min}^{-1}\right)$.

The interaction between $\mathrm{Pt}$ atoms and the supports can change the electronic state of metallic active sites. This effect was studied by infrared spectroscopy of adsorbed CO. The CO-FTIR spectra were recorded at room temperature in a Perkin Elmer Spectrum One spectrometer, in the range $4000-400 \mathrm{~cm}^{-1}$ with a resolution of $4 \mathrm{~cm}^{-1}$. A self-supported wafer of $0.05 \mathrm{~g}$ of the reduced sample was successively outgassed at $10^{-4}$ bar at $773 \mathrm{~K}$ for $30 \mathrm{~min}$ to eliminate water and then reduced with a hydrogen flow at $723 \mathrm{~K}$ for 30 min. After reduction, the cell was outgassed at $10^{-10}$ bar and kept at $773 \mathrm{~K}$ for $30 \mathrm{~min}$, cooled down to room temperature and the first spectrum was taken. After recording the IR spectra, the samples were contacted with 0.04 bar of $\mathrm{CO}$ for $5 \mathrm{~min}$ and then a new spectrum was recorded. The bands of the chemisorbed $\mathrm{CO}$ were obtained by subtraction of both spectra. 


\section{CATALYTIC ACTIVITY IN $\mathrm{CH}_{4}$ DRY REFORMING}

The dry reforming reaction of $\mathrm{CH}_{4}$ was carried out in a continuous reactor with $0.2 \mathrm{~g}$ of catalyst. The catalyst was previously reduced in situ at $823 \mathrm{~K}$ for $3 \mathrm{~h}$ then it was kept in He flow to reach the reaction temperature $(1023 \mathrm{~K})$, similar to those of industrial operation of these catalysts. Moreover additional experiments at 873, 923 and $973 \mathrm{~K}$ (in conditions far from the thermodynamic equilibrium) were carried out. The reactor was fed with $20 \mathrm{~cm}^{3} \mathrm{~min}^{-1}$ of $\mathrm{CH}_{4}$ and $\mathrm{CO}_{2}$ with molar ratio equal to 1 . The reaction time was $200 \mathrm{~min}$. The reaction products were analysed online using a Varian Star 3400 CX gas chromatograph, equipped with a TCD and a column Carboxem 1006. After the reaction, the content of coke deposited on the catalyst was verified by temperature programmed oxidation (TPO) measurements.

Methane conversion $\left(\mathrm{XCH}_{4}\right), \mathrm{CO}_{2}$ conversion $\left(\mathrm{XCO}_{2}\right)$ and $\mathrm{CO} / \mathrm{H}_{2}$ ratio were calculated as follows using the gas composition measured by GC:

$$
\begin{gathered}
\mathrm{X}_{\mathrm{CH}_{4}}=\frac{\mathrm{F}_{\mathrm{CH}_{4 \text { in }}}-\mathrm{F}_{\mathrm{CH}_{4_{\text {out }}}}}{\mathrm{F}_{\mathrm{CH}_{4}}} \times 100 \\
\mathrm{X}_{\mathrm{CO}_{2}}=\frac{\mathrm{F}_{\mathrm{CO}_{2 \text { in }}}-\mathrm{F}_{\mathrm{CO}_{2_{\text {out }}}}}{\mathrm{F}_{\mathrm{CO}_{2_{\text {in }}}}} \times 100
\end{gathered}
$$

\section{RESULTS AND DISCUSSION}

Table 1 shows the BET surface area and the pore volume values of the different supports. The KL zeolite displayed the highest value of $\mathrm{Sg}\left(245 \mathrm{~m}^{2} \mathrm{~g}^{-1}\right)$, while the remaining supports showed similar values between 160 and $176 \mathrm{~m}^{2} \mathrm{~g}^{-1}$. With respect to the porosity, the mean pore volume was around $0.5 \mathrm{~cm}^{3} \cdot \mathrm{g}^{-1}$, except for the $\mathrm{K}(\mathrm{Mg}-\mathrm{Al})$ sample that displayed a slightly higher $\mathrm{Vp}\left(0.663 \mathrm{~cm}^{3} \mathrm{~g}^{-1}\right)$.

The measurements of the density of acid sites of the supports were studied by temperature-programmed desorption of $\mathrm{NH}_{3}$. Table 1 shows that the acidity value of the KL zeolite is only comparable with that of the pure alumina (A) without promoter. In the

Table 1. Values of specific surface area $(\mathrm{Sg})$, pore volume (Vp) and density of acid $\left(\mathrm{n}_{\mathrm{a}}\right)$ and basic $(\mathrm{nb})$ sites of the different supports.

\begin{tabular}{ccccc}
\hline Support & $\begin{array}{c}\mathbf{S g} \\
\left(\mathbf{m}^{\mathbf{2}} / \mathbf{g}\right)\end{array}$ & $\begin{array}{c}\mathbf{V p} \\
\left(\mathbf{c m}^{\mathbf{3}} / \mathbf{g}\right)\end{array}$ & $\begin{array}{c}\mathbf{n}_{\mathbf{a}} \\
(\mu \mathbf{m o l} / \mathbf{g})\end{array}$ & $\begin{array}{c}\mathbf{n}_{\mathbf{b}} \\
(\mu \mathbf{m o l} / \mathbf{g})\end{array}$ \\
\hline $\mathrm{A}$ & 190 & 0.500 & 101 & 3 \\
$\mathrm{KL}$ & 245 & 0.520 & 90 & 23 \\
$\mathrm{KA}$ & 176 & 0.492 & - & 62 \\
$\mathrm{~K}(\mathrm{Mg}-\mathrm{Al})$ & 160 & 0.663 & - & 130 \\
$\mathrm{MgO}$ & 160 & 0.517 & - & 214 \\
\hline
\end{tabular}

other supports, ammonia was not chemisorbed, so the acidity appears to be negligible.

The basicity of the supports was studied by TPD- $\mathrm{CO}_{2}$ and the test reaction of 2-propanol dehydrogenation. Figure 1 shows the TPD-CO desorption profiles for the different supports. The profiles of the different sites overlap, hence they were deconvoluted in order to determine the distribution of the basic strength sites of the different materials. In this figure, three types of basic sites can be observed. A weak basicity (nbW), with a peak of desorption centred at $403 \mathrm{~K}$; a medium basicity (nbM), with a desorption peak at $513 \mathrm{~K}$ and a strong basicity (nbS), with a desorption peak at $643 \mathrm{~K}$. The curves of desorption were deconvoluted into three Gaussian or Lorenzian curves in order to quantify the area corresponding to the different basic sites. The density of the total basic sites (nb) was determined by integration of the area under the corresponding desorption profiles of the different supports. KL zeolite shows a low density of weak and medium basic sites that desorb $\mathrm{CO}_{2}$ below $573 \mathrm{~K}$ (Fig.1). The $\mathrm{K}$ doped alumina (KA) shows weak and medium basic sites with a $\mathrm{CO}_{2}$ desorption up to $623 \mathrm{~K}$, and the mixed oxide $(\mathrm{K}(\mathrm{Mg}-\mathrm{Al})$ with a desorption curve that reached up to $743 \mathrm{~K}$, displays an important amount of weak and medium basic sites and low amount of strong basic sites. On the other hand, $\mathrm{MgO}$ does not show weak basic sites (desorption peak at $423 \mathrm{~K}$ ), but it displays an intermediate zone of medium basic sites and an important desorption peak at very high temperatures (673 K) corresponding to very strong basic sites. The total number of basic sites $(\mathrm{nb})$ is presented in Table 1 and follows the decreasing tendency: $\mathrm{MgO}>\mathrm{K}(\mathrm{Mg}-$ Al) $>$ KA $>$ KL.

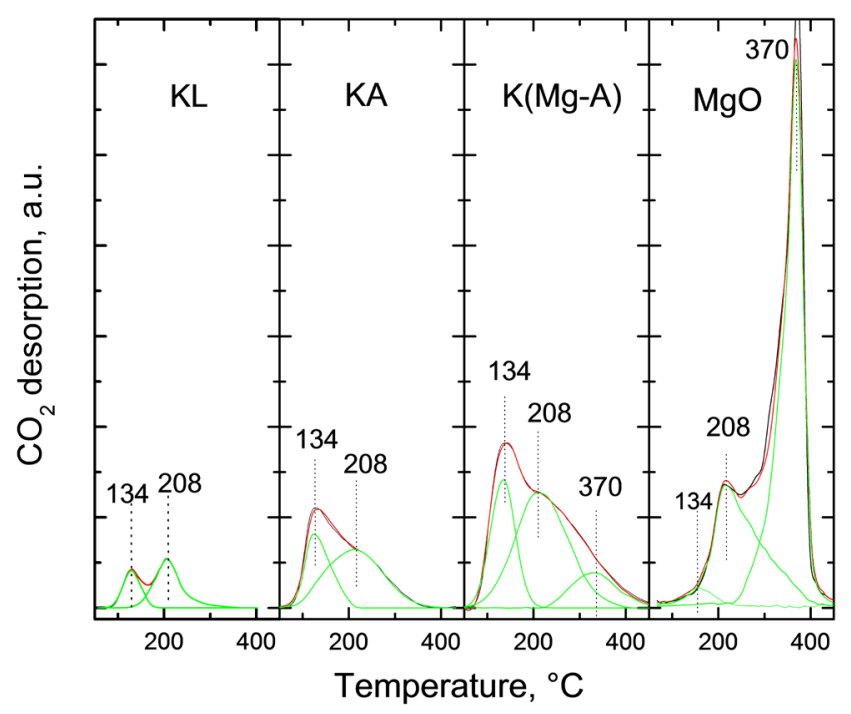

Figure 1. TPD- $\mathrm{CO}_{2}$ profiles of the supports: $\mathrm{KL}$ zeolite, $\mathrm{MgO}, \mathrm{Al}_{2} \mathrm{O}_{3}-\mathrm{K}(\mathrm{KA})$ and mixed oxide $\mathrm{K}(\mathrm{Mg}$ $\mathrm{Al})$ in Weak basicity (nbW), Medium basicity (nbM) and Strong basicity (nbS). 
It is known that acetone production from the 2-propanol dehydrogenation reaction can be carried out on the basic sites of different strength for a catalyst (Gervasini and Auroux 1991). Hence, the study of this reaction on the different supports lets one know the basicity of the materials. Figure 2 also shows the acetone/propylene ratio for the different supports. The basic site density follows the same order as that found from $\mathrm{CO}_{2}$ desorption, this meaning that the mixed oxide $\mathrm{K}(\mathrm{Mg}-\mathrm{Al})$ shows a higher quantity of basic sites than the doped alumina (AK), while the zeolite (KL) has the lowest basicity. Hence, the values of basicity determined by desorption of carbon dioxide agreed with those obtained by the dehydrogenation of 2-propanol. With respect to the data corresponding to $\mathrm{MgO}$, this catalyst is inactive for isopropanol dehydrogenation. Hence, this reaction test is not adequate to know the basic character of determined oxides like $\mathrm{MgO}$ since it does not occur on basic oxides without redox properties (Lahousse and Bachelier, 1994). Although both $\mathrm{A}-\mathrm{K}$ and $\mathrm{K}(\mathrm{Mg}-\mathrm{Al})$ do not have redox properties, they could activate the hydrogen at the reaction temperature, while $\mathrm{MgO}$ cannot at that temperature.

After deposition of $\mathrm{Pt}$ on the different supports, the chemical analysis results (Table 2) showed that the platinum contents of the catalysts were near to the nominal loadings. The characeristcs of the metallic

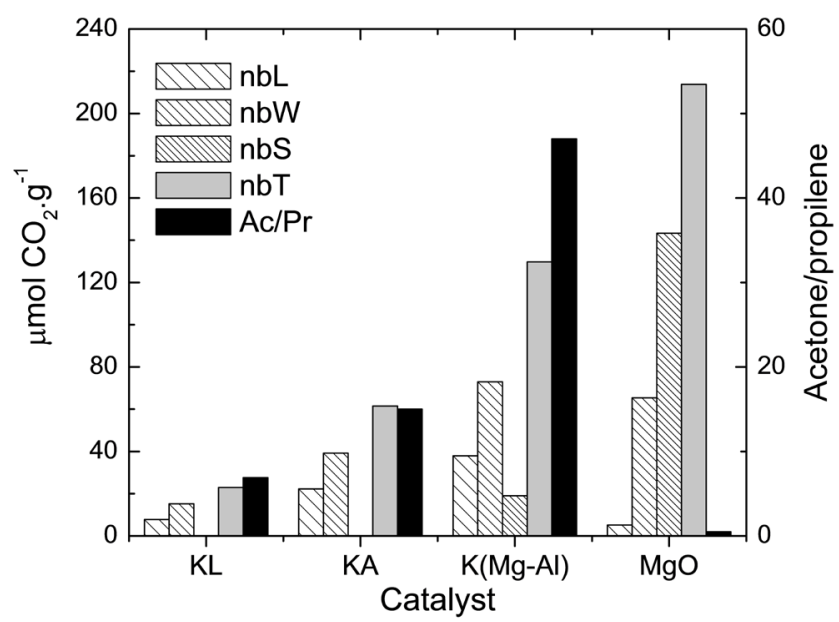

Figure 2. Acetone/propylene ratio obtained from the 2-propanol decomposition reaction and Density of the basic sites (nb) determined from TPD- $\mathrm{CO}_{2}$ profiles of the supports: $\mathrm{KL}$ zeolite, $\mathrm{MgO}, \mathrm{Al}_{2} \mathrm{O}_{3}-\mathrm{K}(\mathrm{KA})$ and mixed oxide $\mathrm{K}(\mathrm{Mg}-\mathrm{Al})$.

Table 2. Pt content and initial rate of cyclohexane dehydrogenation reaction of the Pt-catalysts.

\begin{tabular}{ccc}
\hline Catalysts & $\begin{array}{c}\text { Pt loading } \\
(\mathbf{\%})\end{array}$ & $\begin{array}{c}\mathbf{r}^{\mathbf{0}} \mathbf{( 5 7 3 ~ K )} \\
\left(\mathbf{m o l ~ ~ ^ { - 1 }} \mathbf{~ h}^{-1}\right)\end{array}$ \\
\hline $\mathrm{Pt} / \mathrm{KL}$ & 0.85 & 12.1 \\
$\mathrm{Pt} / \mathrm{KA}$ & 0.99 & 21.5 \\
$\mathrm{Pt} / \mathrm{K}(\mathrm{Mg}-\mathrm{Al})$ & 0.87 & 22.6 \\
$\mathrm{Pt} / \mathrm{MgO}$ & 0.95 & 25.2 \\
\hline
\end{tabular}

function were analyzed by different techniques, such as test reaction, TPR and FTIR.

In orden to determine the metallic dispersion, the catalysts were evaluated by the CHD reaction. This reaction is a structure-insensitive reaction, which is carried out on one site of metallic surface, and it can be considered as an indirect measurement of exposed metallic sites on the catalysts (Blakely and Somorjai, 1976). Table 2 also shows the values of initial reaction rates for cyclohexane dehydrogenation. The values have an experimental error lower than $5 \%$. In all cases, the only product of the reaction of conversion of cyclohexane was benzene. The sample of $\mathrm{Pt}$ supported on $\mathrm{MgO}$ showed the highest value, followed by $\mathrm{Pt} /$ $\mathrm{K}(\mathrm{Mg}-\mathrm{Al})$ and $\mathrm{Pt} / \mathrm{KA}$. Finally, the $\mathrm{Pt} / \mathrm{KL}$ catalyst, with the lowest basicity, displayed the lowest value. Hence the use of basic $\mathrm{MgO}$ as a support of Pt catalysts prepared from organometallic precursors favours the dispersion of the metallic phase, as it has been previously reported (Gamba and Colella, 2001).

The TPR profiles (Figure 3) of the monometallic platinum catalysts supported on $\mathrm{KL}, \mathrm{KA}, \mathrm{K}(\mathrm{Mg}-\mathrm{Al})$ and $\mathrm{MgO}$ show $\mathrm{Pt}$ reduction zones at temperatures between 573 and $773 \mathrm{~K}$. From these profiles it can be ensured that, for all catalysts, $\mathrm{Pt}$ is in metallic state at the reduction temperature $(823 \mathrm{~K})$ previous to the dry reforming reaction.

IR spectra of adsorbed $\mathrm{CO}$ on the different reduced catalysts (Figure 4) show two absorption bands in the CO vibration zone at $v_{\mathrm{CO}}=1800-1755 \mathrm{~cm}^{-1}$ and at $v_{\mathrm{CO}}=1900-2200 \mathrm{~cm}^{-1}$ that correspond to both the bridge and linear $\mathrm{CO}$ adsorption on Pt particles, respectively (Morterra and Aschieri; 2008). The band



Figure 3. TPR profiles of Pt-catalysts supported on $\mathrm{KL}$ zeolite, $\mathrm{MgO}, \mathrm{Al}_{2} \mathrm{O}_{3}-\mathrm{K}(\mathrm{KA})$ and mixed oxide $\mathrm{K}(\mathrm{Mg}-\mathrm{Al})$. 


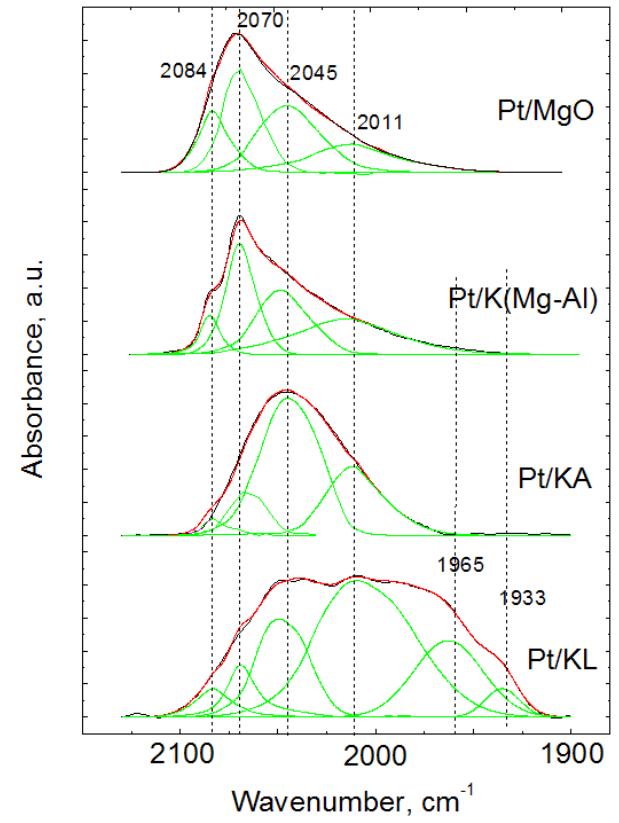

Figure 4. FTIR spectra of adsorbed $\mathrm{CO}$ on the Ptcatalysts supported on $\mathrm{KL}$ zeolite, $\mathrm{MgO}, \mathrm{Al}_{2} \mathrm{O}_{3}-\mathrm{K}$ (KA) and mixed oxide $\mathrm{K}(\mathrm{Mg}-\mathrm{Al})$.

that gives more information about $\mathrm{Pt}$ interaction with the support is the linear $\mathrm{CO}$ adsorption one. Because of this, Figure 4 only shows the bands corresponding to the linear $\mathrm{CO}$ adsorption of the catalysts. This band is composed of different peaks whose position and intensity are modified according to the electronic density of the metallic particles reduced on the surface, this depending on the metal-support (M-S) interaction. In supports with low M-S interaction, this band has a maximum at $v_{\mathrm{CO}}=2075 \mathrm{~cm}^{-1}$ corresponding to the adsorbed $\mathrm{CO}$ over $\mathrm{Pt}^{0}$ (Kustov and Kazansky, 1994). When the metallic dispersion is high and the interaction of the particles with the support is strong, there exist different intensity signals at $v_{\mathrm{CO}}>2075 \mathrm{~cm}^{-1}$ that correspond to $\mathrm{CO}$ adsorbed on electrodeficient $\mathrm{Pt}$, $\mathrm{Pt}^{{ }^{8+}}$ (Ivanov and Kustov, 1998). When the metallic cluster is large and it was deposited on a basic support, there exist different intensity signals at $v_{\mathrm{CO}}<2075 \mathrm{~cm}^{-1}$ that correspond to $\mathrm{CO}$ adsorbed on electroexcedent $\mathrm{Pt}, \mathrm{Pt}^{\delta-}$ (Yu and Kustov, 1999). These signals are very well defined in $\mathrm{Pt} / \mathrm{KL}$ catalysts due to their crystalline structure and are found at $v_{\mathrm{CO}}=2045,2011,1965$ and $1933 \mathrm{~cm}^{-1}$ (Arcoya and Seoane, 2005). The zeolitic structure of KL favors the interaction between the weak and medium basic centers of the support with the $\mathrm{Pt}$ particles, generating large electroexcedent $\mathrm{Pt}$ metal centers. In the other supports, in spite of having more medium and strong basic centers (Fig.1), the electronic transfer from basic centers to metallic particles of $\mathrm{Pt}$ is less efficient, possibly due to the amorphous character of the support. The deconvolution of CO-FTIR signals of the $\mathrm{Pt} / \mathrm{MgO}$ catalyst (which has a high density of strong basic centers) shows that there is an increase in the signal at $2084 \mathrm{~cm}^{-1}$ (with respect to the other catalysts), thus indicating the strongest interaction between Pt and the basic support. $\mathrm{ft}$ is known that by increasing the metal-support interaction, the dispersion of the metallic phase is more likely to be higher.

The catalytic properties of the Pt-catalysts were evaluated in the methane dry reforming to produce syngas $\left(\mathrm{CO}+\mathrm{H}_{2}\right)$ at $1023 \mathrm{~K}$ (industrial conditions). It is worth mentioning that, at this temperature, the more active catalysts reach conversions near the thermodynamic equilibrium. All catalysts were stable through the $200 \mathrm{~min}$ reaction time. The deposited carbon contents were analysed after the reaction, which were negligible in all cases $(<0.01 \mathrm{wt} \% \mathrm{C})$. The catalytic behaviour of the different catalysts at $1023 \mathrm{~K}$ is shown in Figures 5 and 6 and Table 3. Figure 5 shows the evolution of the $\mathrm{CO}_{2}$ and $\mathrm{CH}_{4}$ conversions and the $\mathrm{H}_{2} / \mathrm{CO}$ ratios in the products as a function of time-onstream (TOS). Figure 6 shows the concentrations of $\mathrm{H}_{2}$, $\mathrm{CO}$ and $\mathrm{H}_{2} \mathrm{O}$ in the product as a function of time-onstream in the dry reforming of methane. Table 3 shows the average values of $\mathrm{CO}_{2}$ and $\mathrm{CH}_{4}$ conversions and the $\mathrm{H}_{2} / \mathrm{CO}$ ratios obtained for the different catalysts. The $\mathrm{Pt}$ catalysts supported on $\mathrm{KL}, \mathrm{KA}$ and $\mathrm{K}(\mathrm{Mg}-\mathrm{Al})$ show similar $\mathrm{CO}_{2}$ conversions of about $92 \%$, while for $\mathrm{Pt} /$ $\mathrm{MgO}$ the conversion is higher (about 94\%). It can be observed that methane conversions and $\mathrm{H}_{2} / \mathrm{CO}$ ratios decreased in the following order: $\mathrm{Pt} / \mathrm{MgO}>\mathrm{Pt} / \mathrm{K}(\mathrm{Mg}$ $\mathrm{Al}) \cong \mathrm{Pt} / \mathrm{KA}>\mathrm{Pt} / \mathrm{KL}$. These catalysts were prepared with supports of similar areas but different distribution of basic sites. In this sense, the methane and $\mathrm{CO}_{2}$ conversions and the $\mathrm{H}_{2} / \mathrm{CO}$ ratios correlate well with the basicity of the catalysts. In this sense, the worst catalytic performance of $\mathrm{Pt} / \mathrm{KL}$ catalyst corresponded to the metallic sample supported on a material with the lowest basicity (KL zeolite). On the other hand, the catalyst supported on the material with the highest basicity $(\mathrm{MgO})$ displays the highest $\mathrm{CO}_{2}(\cong 94 \%)$ and $\mathrm{CH}_{4}(83 \%)$ conversions, and the highest $\mathrm{H}_{2} / \mathrm{CO}$ ratio (0.73). Figure 7 shows the results of additional activity measurements in dry reforming at lower temperatures $(873,923$ and $973 \mathrm{~K})$ to confirm the correlation between the catalytic behaviour and the support basicity. At these temperatures the conversions keep away from the thermodynamic equilibrium. These tests were performed with samples of the highest and lowest basicity ( $\mathrm{Pt} / \mathrm{MgO}$ and $\mathrm{Pt} / \mathrm{KL}$, respectively). It can be

Table 3. Average $\mathrm{CH}_{4}$ and $\mathrm{CO}_{2}$ conversion and $\mathrm{H}_{2} / \mathrm{CO}$ ratio for the Pt-catalysts.

\begin{tabular}{cccc}
\hline Catalysts & $\mathbf{X}_{\mathbf{C H} 4}(\mathbf{\%})$ & $\mathbf{X}_{\mathbf{C O 2}}(\mathbf{\%})$ & $\mathbf{H}_{2} / \mathbf{C O}$ \\
\hline $\mathrm{Pt} / \mathrm{KL}$ & 71.1 & 91.5 & 0.50 \\
$\mathrm{Pt} / \mathrm{KA}$ & 75.0 & 92.0 & 0.52 \\
$\mathrm{Pt} / \mathrm{K}(\mathrm{Mg}-\mathrm{Al})$ & 79.0 & 92.8 & 0.58 \\
$\mathrm{Pt} / \mathrm{MgO}$ & 83.0 & 93.6 & 0.73 \\
\hline
\end{tabular}




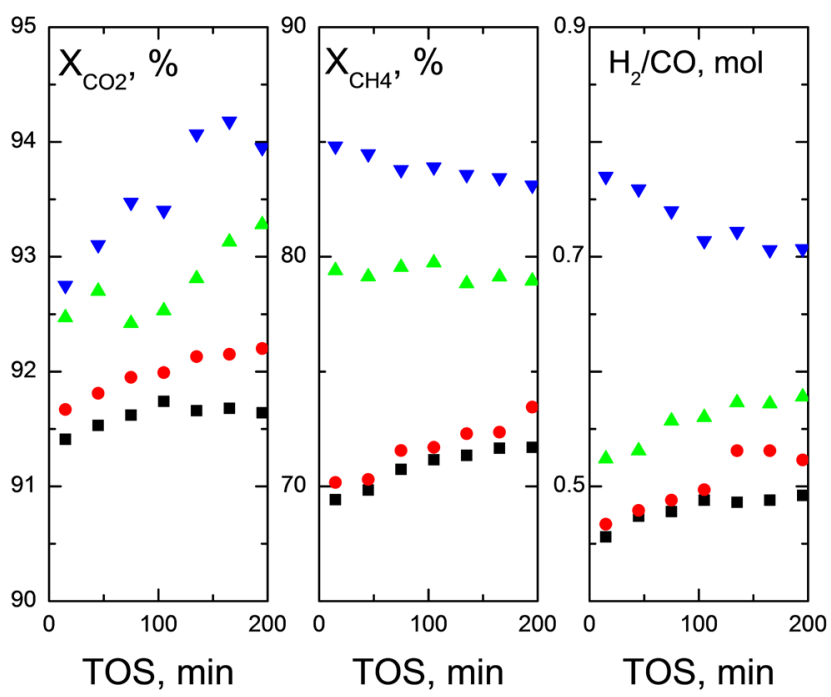

Figure 5. Conversion of $\mathrm{CO}_{2}$ and $\mathrm{CH}_{4}$ and the $\mathrm{H}_{2} / \mathrm{CO}$ ratio in the products as a function of time-on-stream (TOS) in the dry reforming of methane. Symbols: (blue) Pt/MgO; (green) $\mathrm{Pt} / \mathrm{K}(\mathrm{Mg}-\mathrm{Al})$; (red) $\mathrm{Pt} / \mathrm{KA}$ and (black) $\mathrm{Pt} / \mathrm{KL}$.

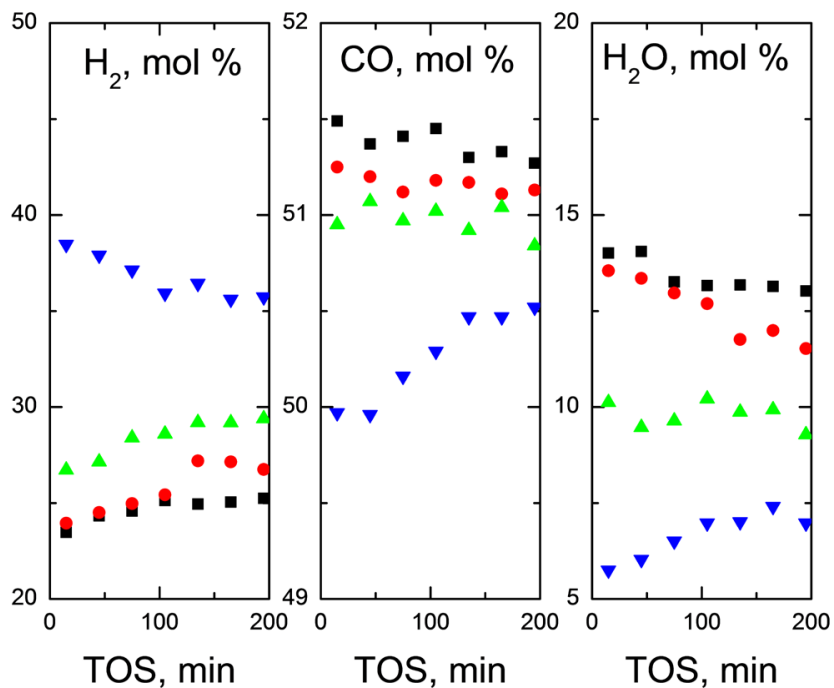

Figure 6. Concentration (as $\mathrm{mol}_{\%}$ ) of $\mathrm{H}_{2}, \mathrm{CO}$ and $\mathrm{H}_{2} \mathrm{O}$ in the product as a function of time-on-stream in the dry reforming of methane. Symbols: idem Fig 5.

observed that, at a lower temperature, the more basic catalyst $(\mathrm{Pt} / \mathrm{MgO})$ displays much higher conversions and generates a higher $\mathrm{H}_{2} / \mathrm{CO}$ ratio than the least basic catalyst $(\mathrm{Pt} / \mathrm{KL})$. Moreover, the differences between the conversions of both catalysts increase at lower temperatures, in conditions far from the equilibrium.

The better catalytic behaviour of the $\mathrm{Pt} / \mathrm{MgO}$ catalyst could be related with the strong interaction between the metallic phase, prepared from an organic precursor, and the most basic support, thus leading to the highest metallic dispersion (Gamba and Colella, 2001). In this sense, the interaction of $\mathrm{Pt}$ with the basic sites of the support should be very important for this reaction. The $\mathrm{Pt}$ catalysts supported on $\mathrm{Pt} / \mathrm{KA}$ and $\mathrm{Pt} / \mathrm{KL}$, whose basicity

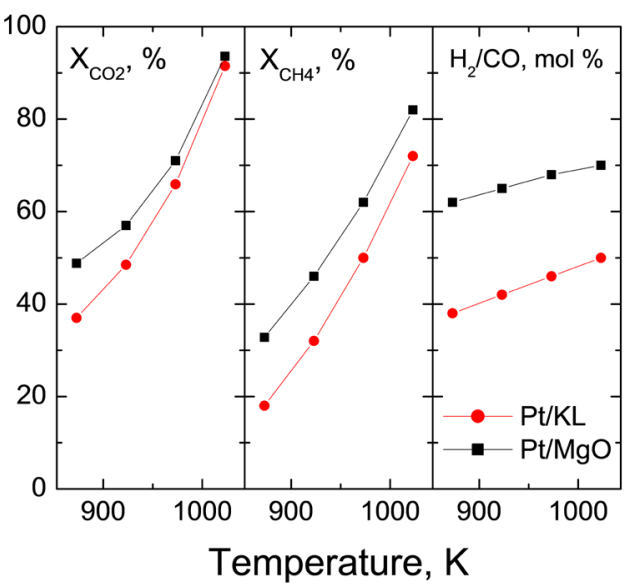

Figure 7. Conversion of $\mathrm{CO}_{2}$ and $\mathrm{CH}_{4}$ and the $\mathrm{H}_{2} /$ $\mathrm{CO}$ ratio in the products as a function of the reaction temperature in the dry reforming of methane.

is lower than $\mathrm{MgO}$ and higher than zeolite $\mathrm{KL}$, have an intermediate catalytic behaviour in the DR reaction. The $\mathrm{Pt} / \mathrm{MgO}$ shows a very good catalytic performance for the DR reaction compared with other results reported in the literature (Fan et al., 2009).

It is important to highlight the high $\mathrm{H}_{2} / \mathrm{CO}$ ratio (0.73) obtained in the product stream for the $\mathrm{Pt} / \mathrm{MgO}$ catalyst, much higher than those obtained for the other catalysts. Considering that the theoretical $\mathrm{H}_{2} / \mathrm{CO}$ molar ratio produced by the dry reforming reaction $\left(\mathrm{CH}_{4}+\mathrm{CO}_{2} \rightarrow \mathrm{CO}+\mathrm{H}_{2}\right)$ is equal to one, the decrease of this value is associated with the reverse water-gas shift reaction (RWGS). This undesirable reaction $\left(\mathrm{CO}_{2}\right.$ $+\mathrm{H}_{2} \leftrightarrows \mathrm{CO}+\mathrm{H}_{2} \mathrm{O}$ ) consumes part of the $\mathrm{H}_{2}$ produced by reforming, which reacts with $\mathrm{CO}_{2}$ to yield $\mathrm{CO}$ and water. In this sense, the results indicate the importance of the $\mathrm{Pt}$ catalyst supported on the basic $\mathrm{MgO}$, since it would inhibit the RWGS reaction, thus producing a higher $\mathrm{H}_{2} / \mathrm{CO}$ ratio than the other catalysts. Figure 7 shows the evolution of the molar concentration of $\mathrm{H}_{2}$, $\mathrm{CO}$ and $\mathrm{H}_{2} \mathrm{O}$ in the products as a function of time-onstream. In agreement with the above results, it can be observed that the $\mathrm{Pt}$ catalyst with the higher density of strong basic sites ( $\mathrm{Pt} / \mathrm{MgO}$ catalyst) displays the higher yield of $\mathrm{H}_{2}$ and the lower yield of $\mathrm{CO}$ and $\mathrm{H}_{2} \mathrm{O}$. This is because this catalyst inhibits the RWGS, thus leading to an increase of the $\mathrm{H}_{2} / \mathrm{CO}$ ratio.

\section{CONCLUSIONS}

From the results presented and discussed above, the following conclusions can be drawn:

(i) A good adsorption of platinum acetylacetonate (II) was obtained during the impregnation step on several supports with different distribution of basic sites. At the reduction temperature $(823 \mathrm{~K})$ previous to the dry reforming reaction and in the presence of $\mathrm{H}_{2}$, $\mathrm{Pt}$ is reduced to the metallic state. 
(ii) The monometallic Pt-catalysts supported on the different materials showed a good and stable activity along the reaction time (both $\mathrm{CH}_{4}$ and $\mathrm{CO}_{2}$ conversions have high and constant values).

(iii) The use of a lightly basic zeolite, like KL, as a catalytic support was not adequate for this reforming reaction because the catalyst shows both the lowest methane and $\mathrm{CO}_{2}$ conversions and $\mathrm{H}_{2} / \mathrm{CO}$ molar ratio.

(iv) $\mathrm{Pt}$ catalysts supported on $\mathrm{MgO}$, with high amounts of strong basic sites displayed very good metallic dispersion, the best catalytic behaviour in dry reforming with respect to activity, and produced the highest $\mathrm{H}_{2} / \mathrm{CO}$ ratio of 0.73 .

(v) The methane conversion and the $\mathrm{H}_{2} / \mathrm{CO}$ ratios obtained for the DR reaction followed a similar tendency corresponding to the basicity of the catalysts.

\section{ACKNOWLEDGMENTS}

Authors thank Mabel Baez for the experimental assistance. This work was financially supported by CAPES-SECyT, CONICET and Universidad Nacional del Litoral (Argentina).

\section{REFERENCES}

Adans Y.F., Ballarini A.D., Martins A.R., Coelho R.E., and Carvalho L.S.; Performance of Nickel Supported on $\gamma$-Alumina Obtained by Aluminum Recycling for Methane Dry Reforming, Catalysis Letters 147, 2057-2066 (2017). https://doi. org/10.1007/s10562-017-2088-3

Al-Doghachi F.J., Zainal Z., Saiman M.I., Embong Z., and Taufiq-Yap Y.H., Hydrogen production from dry-reforming of biogas over $\mathrm{Pt} / \mathrm{Mg}_{1-\mathrm{x}} \mathrm{Ni} \mathrm{O}$ catalysts, Energy Procedia 79, 18-25 (2015). https://doi.org/10.1016/j.egypro.2015.11.460

Alipour Z., Rezaei M. and Meshkani F., Effect of alkaline earth promoters $(\mathrm{MgO}, \mathrm{CaO}$, and $\mathrm{BaO})$ on the activity and coke formation of $\mathrm{Ni}$ catalysts supported on nanocrystalline $\mathrm{Al}_{2} \mathrm{O}_{3}$ in dry reforming of methane, Journal of Industrial and Engineering Chemistry, 20, 2858-2863 (2014). https://doi. org/10.1016/j.jiec.2013.11.018

Arandiyan H. and Parvari M., Preparation of La-Mo-V mixed-oxide systems and their application in the direct synthesis of acetic acid, Journal of Natural Gas Chemistry 17 213- 224 (2008). https://doi. org/10.1016/S1003-9953(08)60054-7

Arcoya A., Seoane X. L. and Grau J. M., Surface characterization and dehydrocyclization activity of $\mathrm{Pt} / \mathrm{KL}$ catalysts prepared by different methods, Applied Surface Science 205, $206-211$ (2005). https://doi.org/10.1016/S0169-4332(02)01089-9

Ballarini A. D., de Miguel S. R., Jablonski E., Scelza O. A. and Castro A. A., Reforming of $\mathrm{CH}_{4}$ with $\mathrm{CO}_{2}$ on Pt-supported catalysts: Effect of the support on the catalytic behaviour, Catalysis Today, 107, 481-486 (2005). https://doi.org/10.1016/j. cattod.2005.07.058

Ballarini A., Basile F., Benito P., Bersani I., Fornasari G., de Miguel S., Maina S. C. P., Vilella J., Vaccari A. and Scelza O.A., Platinum supported on alkaline and alkaline earth metal-doped alumina as catalysts for dry reforming and partial oxidation of methane, Applied Catalysis A 433-434, 1-11 (2012). https:// doi.org/10.1016/j.apcata.2012.04.037

Berdala J., Freund E. and Lynch J. P., J. Berdala, E. Freund, J. Lynch. Genesis of the metallic phase in a highly dispersed catalyst formed from $\mathrm{Pt}$ acetylacetonate on alumina, J. Phys. 47, C8265 - C8-269 (1986). https://doi.org/10.1051/ jphyscol:1986849

Blakely D. N. and Somorjai G.A., The dehydrogenation and hydrogenolysis of cyclohexane and cyclohexene on stepped (high miller index) platinum surfacesJournal of Catalysis, 42, 181-196 (1976). https://doi.org/10.1016/0021-9517(76)90252-9

Coq B., Crabb E., Warawdekar M., Bond G. C., Slaa J. C., Galvagno S., Mercadante L., Ruiz J. G. and Sierra M. C. S., Catalytic and structural properties of ruthenium bimetallic catalysts: Preparation and characterization, Journal of Molecular Catalysis, 1, 92, 107-121 (1994). https://doi.org/10.1016/03045102(94)85006-2

de Menorval L. C., Chaqroune A., Coq B. and Figueras F., Characterization of mono- and bi-metallic platinum catalysts using CO FTIR spectroscopy. Size effects and topological segregation, Journal of Chemical Society Faraday Transactions 93, 37153720 (1997). https://doi.org/10.1039/a702174g

de Miguel S. R., Vilella I. M. J., Maina S. P., San José-Alonso D., Román-Martínez M. C. and Illán-Gómez M., Influence of $\mathrm{Pt}$ addition to $\mathrm{Ni}$ catalysts on the catalytic performance for long term dry reforming of methane, Applied Catalysis A: General, 435-436, 10-18 (2012). https://doi. org/10.1016/j.apcata.2012.05.030

Fan M. S., Abdullah A. Z. and Bhatia S., Catalytic Technology for Carbon Dioxide Reforming of Methane to Synthesis Gas, ChemCatChem, 1, 192-208 (2009). https://doi.org/10.1002/ cctc. 200900025

Gamba A., Colella C. and Coluccia S., Oxide-based systems at the crossroads of chemistry, Studies in Surface Science and Catalysis, 140, 132-139 (2001). https://doi.org/10.1016/S0167-2991(01)80130-0

Gandao Z, Coq B, de Menorval L. C. and Tichit D., Comparative behaviour of extremely dispersed $\mathrm{Pt} /$ $\mathrm{Mg}(\mathrm{Al}) \mathrm{O}$ and $\mathrm{Pt} / \mathrm{Al}_{2} \mathrm{O}_{3}$ for the chemisorption of hydrogen, $\mathrm{CO}$ and $\mathrm{CO}_{2}$, Applied Catalysis A, 147, 395-406 (1996). https://doi.org/10.1016/S0926860X(96)00202-5 
Garcia-Dieguez M., Pieta I. S., Herrera M. C., Larrubia M. A. and Alemany L. J., Nanostructured Pt- and $\mathrm{Ni}$-based catalysts for $\mathrm{CO}_{2}$-reforming of methane, Journal of Catalysis 270, 136 -145 (2010). https:// doi.org/10.1016/j.jcat.2009.12.010

Gervasini A. and Auroux A., Acidity and basicity of metal oxide surfaces II. Determination by catalytic decomposition of isopropanol, Journal of Catalysis, 131, 190-198 (1991). https://doi.org/10.1016/00219517(91)90335-2

Hileman B., Chemical Engineering, N. 2, Green house gas economics: Cotting $\mathrm{CO}_{2}$ to comply with the Kyoto Protocol will have economical costs, but the size of the coasts is unknown, 28-31 (1998). https:// doi.org/10.1021/cen-v076n009.p028

Ivanov A. V and Kustov L. M., Influence of support acidity on electronic state of platinum in oxide systems promoted by $\mathrm{SO}_{4}{ }^{2-}$ anions, Chemical Bulletin, 47, 1061-1066 (1998). https://doi. org/10.1007/BF02503473

Khalesi A., Arandiyan H. and Parvari M., Effects of Lanthanum Substitution by Strontium and Calcium in La-Ni-Al Perovskite Oxides in Dry Reforming of Methane, Chinese Journal of Catalysis, 29, 960-968 (2008). https://doi.org/10.1016/S18722067(08)60079-0

Kustov L. M., Kazansky V. B., Figueras F. and Tichit D., Investigation of the Acidic Properties of $\mathrm{ZrO}_{2}$ Modified by $\mathrm{SO}_{4}{ }^{2-}$ Anions, Journal of Catalysis, 150,143-149 (1994). https://doi.org/10.1006/ jcat.1994.1330

Lahousse C., Bachelier J., Lavalley J. C., LauronPernot H. and Le Govic A. M., Validity of using isopropanol decomposition as a testreaction for the characterization of metal oxides basicity; comparison with results obtained from methylbutynol decomposition, Journal of Molecular Catalysis A, 87, 329-332 (1994). https:// doi.org/10.1016/0304-5102(93)E0232-6

Morterra C., Aschieri R. and Volante M., Surface characterization of zirconium oxide. I. Surface activation and the development of a strong Lewis acidity, Materials Chemistry and Physics, 20, 539-557 (1998). https://doi.org/10.1016/02540584(88)90087-9

Nagaoka K., Takanabe K. and Aika K., Modification of $\mathrm{Co} / \mathrm{TiO}_{2}$ for dry reforming of methane at $2 \mathrm{MPa}$ by $\mathrm{Pt}, \mathrm{Ru}$ or $\mathrm{Ni}$ Applied Catalysis, A, 268, 151-158 (2004). https://doi.org/10.1016/j. apcata.2004.03.029

Ozkara-Aydinoglu S. and Aksoylu A. E., A comparative study on the kinetics of carbon dioxide reforming of methane over $\mathrm{Pt}-\mathrm{Ni} / \mathrm{Al}_{2} \mathrm{O}_{3}$ catalyst: Effect of $\mathrm{Pt} / \mathrm{Ni}$ Ratio, Chemical Engineering Journal 215, 542-549 (2013). https://doi.org/10.1016/j.cej.2012.11.034
Ozkara-Aydinoglu S. and Aksoylu A. E., $\mathrm{CO}_{2}$ reforming of methane over $\mathrm{Pt}-\mathrm{Ni} / \mathrm{Al}_{2} \mathrm{O}_{3}$ catalysts: effects of catalyst composition, and water and oxygen addition to the feed, International Journal of Hydrogen Energy 36, 2950-2959 (2011). https:// doi.org/10.1016/j.ijhydene.2010.11.080

Ozkara-Aydinoglu S., Ozensoy E. and Aksoylu A. E., The effect of impregnation strategy on methane dry reforming activity of $\mathrm{Ce}$ promoted $\mathrm{Pt} / \mathrm{ZrO}_{2}$. International Journal of Hydrogen Energy 34, 9711-9722, (2009). https://doi.org/10.1016/j. ijhydene.2009.09.005

Pakhare D. and Spivey J., Chem. Soc. Rev., A review of dry $\left(\mathrm{CO}_{2}\right)$ reforming of methane over noble metal catalysts ,43, 7813-7837 (2014). https://doi. org/10.1039/C3CS60395D

Reyes P., Pecchi G., Morales M. and Fierro J. L. G., The nature of the support and the metal precursor on the resistance to sulphur poisoning of $\mathrm{Pt}$ supported catalysts, Applied Catalysis A, 163, 145-152 (1997). https://doi.org/10.1016/S0926860X(97)00138-5

Rostrup-Nielsen J. R. and Hansen J. H. B., COReforming of Methane over Transition Metals, Journal of Catalysis, 144, 38-49 (1993). https://doi. org/10.1006/jcat.1993.1312

Sadykov V. A., Gubanova E. L., Sazonova N. N., Pokrovskaya S. A., Chumakova N. A., Mezentseva N. V., Bobin A. S., Gulyaev R. V., Ishchenko A. V., Krieger T. A. and Mirodatos C., Catalysis Today, 171, 140 (2011). https://doi.org/10.1016/j. cattod.2011.04.004

Seo J. G., Youn M. H., Nam I., Hwang S., Chung J. S. and Song I. K., Hydrogen Production by Steam Reforming of Liquefied Natural Gas over Mesoporous $\mathrm{Ni}_{-} \mathrm{Al}_{2} \mathrm{O}_{3}$ Catalysts Prepared by a Co-Precipitation Method: Effect of Ni/Al Atomic Ratio, Catalysis Letters, 130, 410-416 (2009). https://doi.org/10.1007/s10562-009-0024-X

Shelimov B., Lambert J. F., Che M. and Didillon B., Initial Steps of the Alumina-Supported Platinum Catalyst Preparation: A Molecular Study by 195Pt NMR, UV-Visible, EXAFS, and Raman Spectroscopy, Journal of Catalysis, 185, 462-478 (1999). https://doi.org/10.1006/jcat.1999.2527

Stagg S. M., Romeo E., Padró C. and Resasco D. E., Effect of Promotion with $\mathrm{Sn}$ on Supported Pt Catalysts for $\mathrm{CO}_{2}$ Reforming of $\mathrm{CH}_{4}$, Journal of Catalysis, 178, 137-145 (1998). https://doi. org/10.1006/jcat.1998.2146

van Keulen N. J., Hegarty M., Ross J. R.H. and van der Ooesterhamp P. F., The development of platinumzirconia catalysts for the $\mathrm{CO}_{2}$ reforming of methane, Studies in Surface Science and Catalysis, 107, 537-549 (1997). https://doi.org/10.1016/S01672991(97)80387-4 
Walter C. G., Coq B., Figueras F., Boulet M., Competitive reaction of methylcyclohexane and n-hexane over alumina-supported platinum, iridium and ruthenium catalysts, Applied Catalysis A, 133, 95-102 (1995). https://doi.org/10.1016/0926860X(95)00180-8

Womes M., Cholley T., Le Peltier F., Morin S., Didillon B. and Szydlowski-Schildknecht N., Study of the reaction mechanisms between $\mathrm{Pt}(\mathrm{acac})_{2}$ and alumina surface sites: Application to a new refilling technique for the controlled variation of the particle size of $\mathrm{Pt} / \mathrm{Al}_{2} \mathrm{O}_{3}$ catalysts, Applied Catalysis
A, 283, 9-22 (2005). https://doi.org/10.1016/j. apcata.2004.12.030

Womes M., Lynch J., Bazin D., Le Peltier F., Morin S. and Didillon B., Interaction Between $\mathrm{Pt}(\mathrm{acac})_{2}$ and Alumina Surfaces Studied by XAS, Catalysis Letters 85, 25-31, (2003). https://doi. org/10.1023/A:1022108521955

Yu StakheevA. and Kustov L. M., Effects of the support on the morphology and electronic properties of supported metal clusters: modern concepts and progress in 1990s, Applied Catalysis A, 188, 3-35 (1999). https:// doi.org/10.1016/S0926-860X(99)00232-X 